\title{
Evaluation of Surface Water Quality Impacted by Sewage Overflows from Animal and Residential Lagoon Systems using Principal Component Analysis
}

\author{
Abua Ikem ${ }^{1 *}$, Bob Broz ${ }^{2}$, Jimmie Garth ${ }^{1}$, Samson Tesfaye ${ }^{1}$ and Lin Chung-Ho ${ }^{3}$ \\ ${ }^{1}$ Department of Agriculture and Environmental Sciences, Lincoln University, 904 Chestnut Street, Jefferson City, Missouri 65101, USA \\ ${ }^{2}$ Department of Agricultural Engineering, University of Missouri, Columbia, Missouri 65211, USA \\ ${ }^{3}$ Center for Agroforestry and Department of Forestry, University of Missouri, Columbia, Missouri 65211, USA
}

\begin{abstract}
This study was conducted to: (1) evaluate the water quality of Gans Creek (Missouri, United States), (2) assess the physical and chemical characteristics of two sewage lagoon overflows (confined animal lot lagoon overflow: CALLO, and domestic sewage lagoon overflow: DSLO) discharged into Gans Creek, and (3) understand the most significant analytical variables and major controlling processes influencing Gans Creek water quality using principal component analysis (PCA). Monthly (May 2009-February 2010) sampling was conducted along Gans Creek and at lagoon overflow points. Ammonia-nitrogen $\left(\mathrm{NH}_{3}-\mathrm{N}\right)$ in Gans Creek and the overflows was monitored for another year (March 2010-July 2011) because of its potential toxicity to stream health. Thirty-one variables including $\mathrm{pH}$, electrical conductivity (EC), elemental and anionic species, total nitrogen (TN) and total organic carbon (TOC) were measured in samples. We observed that DSLO samples had the highest level of $\mathrm{NH}_{3}-\mathrm{N}$, total phosphorus (TP), TN, TOC and boron (B) compared to the corresponding levels in both CALLO and Gans Creek samples. Major stressors for this stream system were dissolved materials and ammonia. PCA showed that the first four rotated components (RC1, RC2, RC3 and RC4) accounted for approximately $60 \%$ of the total variability of the dataset. Mineralization (RC1: $20 \%$ ), sewage overflows (RC2: 19\%), diffuse pollution (RC3: 12\%), and runoffs from cattle grazing areas (RC4: 9\%) were the major controlling processes at the study area. Over twenty water quality determinands were significant in the rotated components. Overflows from the lagoon systems need consistent treatment and management for adequate protection of Gans Creek ecosystem.
\end{abstract}

Keywords: Surface water; Confined Animal Lot Lagoon Overflow (CALLO); Domestic Sewage Lagoon Overflow (DSLO); Principal Component Analysis (PCA)

\section{Introduction}

The efficiency of animal agriculture in the United States has increased in over half a century, but environmental degradation is one of the major concerns of the populace [1]. In the United States, fortyfour (44) percent of assessed river and stream miles were reported impaired by the United States Enviromental Protection Agency (EPA). The leading causes of this impairment included pathogens, mercury, nutrients, organic enrichment and low amount of dissolved oxygen. The major sources of impairment as reported, were attributed to atmospheric deposition, agriculture, hydrologic modifications, and unspecified sources [2]. In the State of Missouri, about 286 stream miles have been classified as impaired by point source wastewater discharges. Animal agriculture is prominent, and there are currently 427 Class I concentrated animal feeding operations (CAFOs) located in Missouri. These are operations containing at least 1,000 beef cattle, 2,500 large swine, or 100,000 broiler chickens [3]. Discharge of sewage-derived nitrogen as ammonia can accelerate eutrophic conditions and create toxicity problems to aquatic organisms [4]. Sewage can also be a source of several pollutants into surface waters, and previous articles reported the presence of pharmaceutical compounds [5,6], Escherichia coli and micropollutants [7], hormones [8], polyfluorinated compounds [9], volatile organic compounds [10] and potentially toxic elements [11] in both sewage effluents and surface waters.

Apart from pollution caused by animal agriculture, domestic septic tank systems are equally significant pollution sources to surface waters and can impact local stream chemistries and ecology [12]. For example, export of nutrients (nitrogen and phosphorus) from inland waters to downstream areas is creating hypoxia conditions and dead zones [13] in the Gulf of Mexico. Wastewater systems generally can be classified as decentralized or centralized. Decentralized wastewater systems, often called "septic" or "on-site" systems, derive their name from their location. They treat wastewater close to the source, typically providing treatment on the property of individual homes or businesses. Decentralized systems also include systems serving clusters of individual homes, large capacity septic systems, and a small collection of treatment systems. These systems also treat wastewater close to the source, using small pipes for collecting small volumes of domestic wastewater, unlike centralized urban wastewater treatment systems that pipe large amounts of wastewater many miles through sewers prior to reaching the treatment facility [14]. A septic tank system is designed as a settlement chamber allowing for anaerobic reduction of organic and suspended materials in wastewater [15]. The high conversion rate of organic-nitrogen to ammonium is usually achieved in septic systems but usually fails to lower TN loads.

The study area, Gans Creek is one of several Creeks in Columbia City, Missouri that drains the Lower Missouri-Moreau River basin.

*Corresponding author: Abua Ikem, Department of Agriculture and Environmental Sciences, Lincoln University, 904 Chestnut Street, Jefferson City, Missouri 65101,USA, Tel: +1-573-681-5384; Fax: +1-573-681-5955; E-mail: Ikema@Lincolnu.edu

Received October 02, 2013; Accepted October 22, 2013; Published October 25, 2013

Citation: Ikem A, Broz B, Garth J, Tesfaye S, Lin C (2013) Evaluation of Surface Water Quality Impacted by Sewage Overflows from Animal and Residential Lagoon Systems using Principal Component Analysis. J Environ Anal Toxicol 3: 197. doi: 10.4172/2161-0525.1000197

Copyright: (c) 2013 lkem A, et al. This is an open-access article distributed under the terms of the Creative Commons Attribution License, which permits unrestricted use, distribution, and reproduction in any medium, provided the original author and source are credited. 
Citation: Ikem A, Broz B, Garth J, Tesfaye S, Lin C (2013) Evaluation of Surface Water Quality Impacted by Sewage Overflows from Animal and Residential Lagoon Systems using Principal Component Analysis. J Environ Anal Toxicol 3: 197. doi: 10.4172/2161-0525.1000197

Page 2 of 8

Diffuse pollution at Gans Creek upstream areas and point pollution sources from sewage wastewater overflows (domestic and confined animal lot lagoon systems) threaten Gans Creek ecosystem health. To protect ecosystems and adequately manage export of nutrients from inland waters requires an understanding of ecosystem conditions and the influence of both diffuse and point pollution on water quality. The objectives of this study are threefold: (1) to assess the water quality of Gans Creek at upstream, midstream and downstream sites, (2) measure the physical and chemical characteristics of sewage overflows (CALLO and DSLO) and assess their influence on Gans Creek water quality, and finally, (3) to ascertain the significant analytical variables and controlling processes influencing Gans Creek water quality using principal component analysis (PCA).

\section{Materials and Methods}

\section{Site description and sampling}

Missouri has an area of 69,000 square miles and a population of 5.6 million people, according to the 2000 census. About half of this population is concentrated on opposite sides of the State in the Kansas City and St. Louis metro areas, leaving most of other areas of the State and its waters rural in nature. Surface and groundwater in Missouri are quite varied in quantity and quality, corresponding closely with its geology and land use. There are currently 22,370.3 miles of classified streams in Missouri, 82,126 miles of unclassified streams, and 456 classified lakes totaling 293,696 acres [16].

The study area was Gans Creek, one of several streams in Columbia (County of Boone), Missouri, United States. Gans Creek is a tributary of Little Bonne Femme Creek in Boone County south of Columbia. The stream is designated as category A for the whole body contact recreation use. Gans Creek was first listed as impaired by bacteria in Missouri 2012 303(d) list of impaired waters, which was approved in whole by the U.S. Environmental Protection Agency on Nov. 13, 2012. Missouri's whole body contact bacteria criteria are based on specific levels of risk of acute gastrointestinal illness. The level of risk correlating to the category A criterion is no more than 8 illnesses per 1,000 swimmers in fresh water [16]. Gans Creek, is listed in the Missouri-Moreau watershed with a size of $8816 \mathrm{~km} 2$ and human population density of 220.4 persons per square $\mathrm{km}$. The watershed elevation ranged from 183 to $274 \mathrm{~m}$, and land use is characterized by $17.2 \%$ cropland, $35.7 \%$ grassland, $37.3 \%$ forest, $1.7 \%$ wetland, $6.9 \%$ development and $1.3 \%$ water. The main type of soil classification is silty loam with average annual precipitation of approximately $1.1 \mathrm{~m}$ per year. Flooding of Gans Creek is common after after heavy precipitation.

Missouri State has extensive farm lands, accounting for $66 \%$ of its land use. Major crops are corn, soybean. Animal agriculture (poultry, hog and beef production) also is significant in Missouri. The University of Missouri animal lot facility contained approximately 700 animals (mainly cattle). Five hundred (500) of these animals were fed concentrate meals, and the remaining animals were allowed to graze on farmland most times of the year. Periodically, grazing land was sprayed with confined animal lot wastewater stored in a lagoon within the facility. In another scenario at the study area, the DSLO located on the southeastern portion of the study area, consisted of approximately 100 trailers that housed an average of 4 individuals per trailer. An overflow pipe from the aerated single cell lagoon discharged wastewater through a ditch into Gans Creek. The overflow from the domestic lagoon was discharged every week of the year except during dry periods. Figure 1 presents the aerial map of the sampling area (Gans Creek, beef facility and residential Park) and the designated sample collection points are described in Table 1. Four sampling points were designated along Gans
Creek that represented upstream (G1), midstream (G2) and downstream (G3 and G4) positions with respect to streamflow direction. The sewage wastewater overflows (CALLO and DSLO) were represented by (H1), and (T1) respectively. The combined sewage wastewater overflows (H1 and $\mathrm{T} 1$ ) were represented by $\mathrm{TH} 1$ and $\mathrm{TH} 2$ along a ditch that flowed by gradient into Gans Creek. The mixing zone of the combined wastewaters and Gans Creek was between G2 and G3 sites. Monthly sampling was conducted throughout the study period using a grab sampler except in January 2010 because of freezing conditions. Three types of samples were collected at the sites: (1) samples for $\mathrm{pH}$, chloride $(\mathrm{Cl}-)$, nitrate-nitrogen $\left(\mathrm{NO}_{3}-\mathrm{N}\right)$, nitrite-nitrogen $\left(\mathrm{NO}_{2}-\mathrm{N}\right)$ and $\mathrm{NH}_{3}-\mathrm{N}$ determination, (2) samples for elemental measurement, and (3) samples for TOC and TN analysis. Sampling containers and preservation were implemented according to recommended procedures [17]. All samples were transported to the laboratory on ice-coolers and immediately placed in the refrigerator at $4^{\circ} \mathrm{C}$ in our laboratory and later analyzed for various water quality determinands.

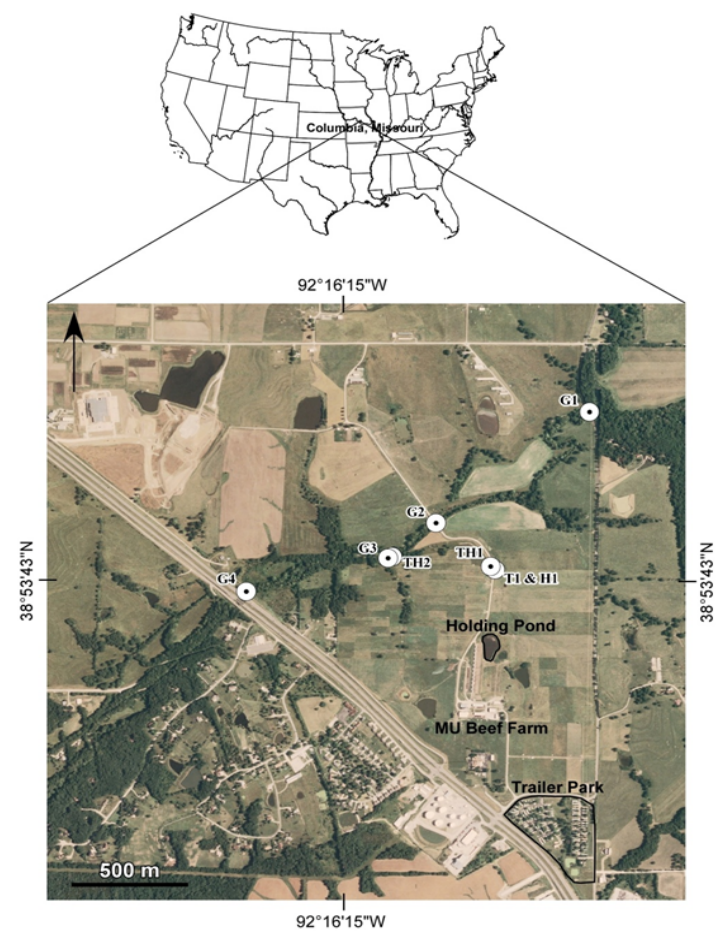

Figure 1: Aerial photograph showing the University of Missouri beef farm lagoon, residential Park and a segment of Gans Creek in Columbia, Missouri (United States)

\begin{tabular}{|c|c|}
\hline Sample labels & Sampling station description \\
\hline T1 & Domestic sewage lagoon overflow (DSLO) \\
\hline $\mathrm{H} 1$ & Confined animal lot lagoon overflow (CALLO) \\
\hline TH1 & $\begin{array}{l}\text { Mixed wastewater overflows from DSLO and CALLO (T1 and } \\
\text { H1)-Sample } 1\end{array}$ \\
\hline $\mathrm{TH} 2$ & $\begin{array}{l}\text { Mixed wastewater overflows from DSLO and CALLO (T1 and } \\
\text { H1)-Sample } 2\end{array}$ \\
\hline G1 & Gans creek most upstream sample \\
\hline G2 & $\begin{array}{l}\text { Gans creek mid stream sample before entry of } \mathrm{H} 1 \text { and } \mathrm{T} 1 \text { into } \\
\text { Gans Creek }\end{array}$ \\
\hline G3 & $\begin{array}{l}\text { Gans creek mid stream sample after entry of H1 and T1 into } \\
\text { Gans Creek }\end{array}$ \\
\hline G4 & Gans creek most downstream sample \\
\hline
\end{tabular}

Table 1: Description of sampling points. 
Citation: Ikem A, Broz B, Garth J, Tesfaye S, Lin C (2013) Evaluation of Surface Water Quality Impacted by Sewage Overflows from Animal and Residential Lagoon Systems using Principal Component Analysis. J Environ Anal Toxicol 3: 197. doi: 10.4172/2161-0525.1000197

Page 3 of 8

\section{Sample measurements}

The $\mathrm{pH}$ and $\mathrm{EC}$ of samples were measured using the Thermo Orion $\mathrm{pH} / \mathrm{ORP} /$ conductivity meter (Model 555A) purchased from Fisher Scientific (Hanover Park, IL 60133, USA). Appropriate buffer solutions were utilized to calibrate the meter before measurements were taken. The variables $\mathrm{Cl}^{-}, \mathrm{NO}_{3}-\mathrm{N}, \mathrm{NO}_{2}-\mathrm{N}$ and $\mathrm{NH}_{3}-\mathrm{N}$ were quantified spectrophotometrically using the mercuric thiocyanate (method 8113), cadmium reduction (method 8039), ferrous sulfate (method 8153 ), and ammonia salicylate (method 8155 ) procedures respectively (Hach, Loveland, Colorado, USA). TOC and TN concentrations in samples were determined on the Shimadzu TOC/TN analyzer. Carbon and nitrogen analysis were by the nondispersive infrared (NDIR) and chemiluminescence detection techniques respectively (Shimadzu Scientific Instruments, Columbia, MD 21046, USA). Carbon and nitrogen experiments were validated with known standards during every batch run. The analytical recoveries obtained for carbon and nitrogen standards ranged from 95-102\%. For elemental species measurement, samples from Gans Creek and the wastewaters were first nitric acid digested using the Ethos EZ microwave digester supplied by Milestone Inc. (Controls Dr. Shelton, CT 06484, USA). Sample digestion process was initiated by the addition of $5 \mathrm{ml}$ nitric acid to $45 \mathrm{ml}$ of sample, and the mixture was subjected to microwave digestion process (Step 1: $160^{\circ} \mathrm{C}$ for $10 \mathrm{~min}$ at $1050 \mathrm{~W}$ and finally, Step 2: $165^{\circ} \mathrm{C}$ for 10 $\mathrm{min}$ at $1050 \mathrm{~W}$ ). The cooled digests were then placed in acid washed LDPE bottles ( $60 \mathrm{ml}$ capacity) and later analyzed with the Varian VistaPro CCD simultaneous inductively coupled plasma-optical emission spectrometer (ICP-OES) (Varian Inc., California, USA). The ICP-OES was calibrated with diluted mixed standards containing aluminum (Al), $\mathrm{B}$, sodium $(\mathrm{Na})$, calcium $(\mathrm{Ca})$, copper $(\mathrm{Cu})$, magnesium $(\mathrm{Mg})$, arsenic (As), barium $(\mathrm{Ba})$, cadmium $(\mathrm{Cd})$, cobalt $(\mathrm{Co})$, potassium $(\mathrm{K})$, iron $(\mathrm{Fe})$, lead $(\mathrm{Pb})$, sulfur $(\mathrm{S})$, manganese $(\mathrm{Mn})$, nickel $(\mathrm{Ni})$, strontium $(\mathrm{Sr})$, vanadium $(\mathrm{V})$, zinc $(\mathrm{Zn})$, mercury $(\mathrm{Hg})$ and total phosphorus $(\mathrm{TP})$. A certified standard reference material (SRM 1643e-trace elements in water) purchased from the National Institute of Standards and Technology (NIST) was used to validate the accuracy of our analytical method. The recoveries of the elements in SRM 1643e ranged from 90$108 \%$. Method blanks were also analyzed for every batch of samples and recalibration of the elements was conducted in sets of 10 samples.

\section{Statistical data analysis}

Data summary, plots and diagrams: Microsoft Excel (Microsoft Office $^{\circledR}$ ) was used for basic data summary. In addition, time series plots and piper diagrams were prepared with AqQA version 1.1 software (Rockware Inc.).

Principal Component Analysis (PCA): Data treatment produce pictorials and summary data information that are easy to interpret. Principal component analysis (PCA), hierarchical cluster analysis (HCA), factor analysis (FA), discriminant analysis (DA) are statistical tools that have been utilized to summarize large datasets by several authors [18-21]. PCA can explain variability in water quality datasets, identify the most important analytical variables and also assist in predicting the controlling processes that influence water quality. PCA models the hidden data structure, explain any similarities and differences among samples, and provide correlations among variables [22]. As earlier reported [23], PCA and principal factor analysis (PFA) normally involve the following five major steps: (1) start by coding the variables $\mathrm{x}_{1}, \mathrm{x}_{2}, \ldots, \mathrm{x}_{\mathrm{p}}$ to have zero means and unit variance; i.e., standardization of the measurements to ensure that they all have equal weights in the analysis; (2) calculate the covariance matrix C; (3) find the eigenvalues $\lambda_{1}, \lambda_{2}, \ldots, \lambda_{\mathrm{p}}$ and the corresponding eigenvectors $\mathrm{a}_{1,} \mathrm{a}_{2}, \ldots$, $\mathrm{a}_{\mathrm{p}}$; (4) discard any components that only account for a small proportion of the variation in datasets; and (5) develop the factor loading matrix and perform a varimax rotation on the factor loading matrix to infer the principal stations. The first few principal components (PCs) will tend to explain a large percentage of the total variance of the dataset and may be used to describe variation in water quality across the study area. Often these patterns are related to specific sources of contamination [24]. Details of PCA techniques and explanation can be found in published literature $[22,25]$.

To extract important variables that controlled Gans Creek study area, we used our dataset consisting of 8 sampling stations and 31 analytical variables ( $\mathrm{pH}, \mathrm{EC}, \mathrm{Al}, \mathrm{As}, \mathrm{Ba}, \mathrm{Na}, \mathrm{Mg}, \mathrm{K}, \mathrm{Ca}, \mathrm{Cd}, \mathrm{Cr}, \mathrm{Co}, \mathrm{Cu}$, $\mathrm{Fe}, \mathrm{B}, \mathrm{Pb}, \mathrm{Ni}, \mathrm{Mn}, \mathrm{Sr}, \mathrm{V}, \mathrm{Zn}, \mathrm{Hg}$, ammonium $\left(\mathrm{NH}_{4}^{+}\right)$, nitrate $\left(\mathrm{NO}_{3}^{-}\right)$, nitrite $\left(\mathrm{NO}_{2}{ }^{-}\right)$, chloride $\left(\mathrm{Cl}^{-}\right)$, sulfate $\left(\mathrm{SO}_{4}^{2-}\right)$, TN, phosphate $\left(\mathrm{PO}_{4}^{3-}\right)$, inorganic carbon (IC) and TOC. The number of PCs extracted to enable us explain the underlying data structure was based on the "Kaiser criterion" [26] where only factors with eigenvalues greater than unity were retained. Our dataset was subjected to PCA procedure after varimax rotation to ascertain the controlling variables and to help predict their sources. PCA was conducted using SPSS 16.0 for Windows software [27].

\section{Results and Discussion}

\section{Physico-chemical characteristics of lagoon overflows}

The summary data of Gans Creek water quality and the lagoon overflows is presented in Table $2 \mathrm{a}$ and $\mathrm{b}$. The $\mathrm{pH}$ of CALLO and DSLO ranged from 7.50-8.00 during the four seasons combined, and values within this range were below the EPA stipulated guideline for drinking water [28]. The trend of major ionic species in both overflows were: $\mathrm{Ca}>\mathrm{Na}>\mathrm{Mg}>\mathrm{K}>\mathrm{NH}_{4}^{+}>\mathrm{Mn}$ (cationic species), and $\mathrm{SO}_{4}^{3-}>$ bicarbonate $\left(\mathrm{HCO}_{3}^{-}\right)>\mathrm{Cl}^{-}>$nitrate $\left(\mathrm{NO}_{3}{ }^{-}\right)>$phosphate $\left(\mathrm{PO}_{4}^{3-}\right)$ (anionic species). Piper trilinear plot was used to classify the ionic composition of DSLO and CALLO. The piper plots are presented as percentages of milliequivalents in two base triangles. Figure 2a shows that DSLO samples consisted of $\mathrm{Ca}^{2+}-\mathrm{Cl}^{-}$type, mixed $\mathrm{Ca}^{2}+-\mathrm{Mg}^{2}+-\mathrm{Cl}^{-}$type and mixed $\mathrm{Ca}^{2+}-\mathrm{Na}^{+}-\mathrm{HCO}_{3}$ type ionic compositions. The DSLO samples were alkaline earth metals with high or moderate chloride concentrations. CALLO samples (Figure 2b) represented to a great extent a $\mathrm{Ca}^{2++}-\mathrm{Mg}^{2}+-\mathrm{Cl}^{-}-\mathrm{SO}_{4}^{3-}$ type water type and dominated by $\mathrm{Ca}^{2+}$ and $\mathrm{SO}_{4}^{3-}$ ions. The nature of the ionic composition of the lagoon overflows is influenced by the activities at the beef facility and residential Park. EC values of the overflows (DSLO: 878 $\mu \mathrm{S} \mathrm{cm} \mathrm{cm}^{-1}$ and CALLO: $1281 \mu \mathrm{S} \mathrm{cm}^{-1}$ ) were pronounced during the winter period because of elevated concentration of dissolved salts. DSLO samples generally had the highest $\mathrm{NH}_{3}-\mathrm{N}$ levels (Figure 2c) compared to CALLO samples. The sources of $\mathrm{NH}_{3}-\mathrm{N}$ in DSLO and CALLO were attributed to organic matter decomposition and urea hydrolysis. The concentration of $\mathrm{B}$ in DSLO was highest during the spring period $\left(\mathrm{B}=0.367 \mathrm{mg} \mathrm{L}^{-1}\right)$. The sources of $\mathrm{B}$ in sewage overflows were detergent products and boron do not substantially adsorb in the sewer system and not easily removed during sewage treatment processes [29].

The water quality data was summarized and reported as annual averages. The annual average recorded for $\mathrm{NH}_{3}-\mathrm{N}$ in DSLO samples (T1=8.48 $\mathrm{mg} \mathrm{L}^{-1}$ ) was at least 13 -folds higher than the corresponding observed annual average for CALLO $\left(\mathrm{H} 1=0.68 \mathrm{mg} \mathrm{L}^{-1}\right)$ samples. The concentration of TP in DSLO $\left(\mathrm{T} 1=2.37 \mathrm{mg} \mathrm{L}^{-1}\right)$ was approximately 4 -folds higher than the observed annual average obtained for CALLO $\left(\mathrm{H} 1=0.63 \mathrm{mg} \mathrm{L}^{-1}\right)$ samples. However, the annual average recorded for TOC in CALLO and DSLO samples were comparable. CALLO samples had the highest annual average for $\mathrm{EC}, \mathrm{Ca}, \mathrm{Mg}, \mathrm{K}, \mathrm{Mn}$, and $\mathrm{SO}_{4}^{3}$ 
Citation: Ikem A, Broz B, Garth J, Tesfaye S, Lin C (2013) Evaluation of Surface Water Quality Impacted by Sewage Overflows from Animal and Residential Lagoon Systems using Principal Component Analysis. J Environ Anal Toxicol 3: 197. doi: 10.4172/2161-0525.1000197

Page 4 of 8

\begin{tabular}{|c|c|c|c|c|c|c|c|c|c|c|c|c|}
\hline \multirow[t]{2}{*}{ Variable } & \multicolumn{2}{|c|}{ G1 } & \multicolumn{2}{|c|}{ G2 } & \multicolumn{2}{|c|}{ G3 } & \multicolumn{2}{|c|}{ G4 } & \multicolumn{2}{|c|}{ T1 } & \multicolumn{2}{|c|}{ H1 } \\
\hline & Average & Stdev & Average & Stdev & Average & Stdev & Average & Stdev & Average & Stdev & Average & Stdev \\
\hline $\mathrm{pH}$ & 7.41 & 0.16 & 7.47 & 0.07 & 7.57 & 0.12 & 7.59 & 0.13 & 7.54 & 0.13 & 7.61 & 0.22 \\
\hline EC & 296.88 & 82.82 & 305.24 & 75.38 & 323.72 & 89.51 & 342.86 & 84.59 & 699.67 & 110.54 & 886.44 & 182.28 \\
\hline TDS & 198.91 & 55.49 & 204.51 & 50.51 & 216.89 & 59.97 & 229.71 & 56.68 & 468.78 & 74.06 & 593.92 & 122.13 \\
\hline IC & 23.11 & 9.98 & 23.16 & 9.25 & 25.16 & 11.61 & 26.34 & 10.07 & 50.85 & 19.02 & 49.39 & 19.72 \\
\hline TOC & 17.88 & 14.01 & 18.36 & 15.05 & 18.91 & 12.39 & 20.04 & 17.97 & 29.49 & 22.98 & 37.00 & 28.09 \\
\hline $\mathrm{Cl}^{-}$ & 10.04 & 2.76 & 9.98 & 2.37 & 10.83 & 2.60 & 14.89 & 4.85 & 30.72 & 14.40 & 15.45 & 4.78 \\
\hline TN & 1.17 & 0.63 & 1.10 & 0.67 & 1.05 & 1.18 & 0.62 & 0.44 & 10.10 & 7.82 & 1.53 & 0.57 \\
\hline $\mathrm{NO}_{3}-\mathrm{N}$ & 1.10 & 0.62 & 1.02 & 0.70 & 0.87 & 1.19 & 0.54 & 0.46 & 1.80 & 0.99 & 0.83 & 0.49 \\
\hline $\mathrm{NO}_{3}^{-}$ & 4.86 & 2.75 & 4.52 & 3.10 & 3.83 & 5.24 & 2.41 & 2.02 & 7.94 & 4.37 & 3.68 & 2.17 \\
\hline $\mathrm{NO}_{2}-\mathrm{N}$ & 0.01 & 0.01 & 0.01 & 0.01 & 0.01 & 0.01 & 0.01 & 0.01 & 0.07 & 0.05 & 0.02 & 0.01 \\
\hline $\mathrm{NH}_{3}-\mathrm{N}$ & 0.06 & 0.04 & 0.07 & 0.06 & 0.17 & 0.15 & 0.07 & 0.05 & 8.24 & 8.48 & 0.68 & 0.63 \\
\hline $\mathrm{NH}_{4}+$ & 0.08 & 0.05 & 0.08 & 0.07 & 0.21 & 0.19 & 0.09 & 0.06 & 10.05 & 10.34 & 0.83 & 0.77 \\
\hline $\mathrm{SO}_{4}{ }^{3}-$ & 49.23 & 15.98 & 53.49 & 14.96 & 54.88 & 18.19 & 47.30 & 12.21 & 43.39 & 34.80 & 254.60 & 148.98 \\
\hline
\end{tabular}

Table 2a: Summary data of general parameters (in mg/l except EC: $\mu \mathrm{S} / \mathrm{cm}$ and pH: no unit) for Gans Creek (G1, G2, G3, G4), domestic sewage lagoon overflow (T1) and confined animal lot lagoon overflow (H1) for the sampling period May 2009-April 2010.

\begin{tabular}{|c|c|c|c|c|c|c|c|c|c|c|c|c|}
\hline \multirow[t]{2}{*}{ Variable } & \multicolumn{2}{|c|}{ G1 } & \multicolumn{2}{|c|}{ G2 } & \multicolumn{2}{|c|}{ G3 } & \multicolumn{2}{|c|}{ G4 } & \multicolumn{2}{|c|}{ T1 } & \multicolumn{2}{|c|}{ H1 } \\
\hline & Average & Stdev & Average & Stdev & Average & Stdev & Average & Stdev & Average & Stdev & Average & Stdev \\
\hline B & 0.04 & 0.01 & 0.04 & 0.01 & 0.04 & 0.02 & 0.04 & 0.01 & 0.22 & 0.11 & 0.06 & 0.02 \\
\hline TP & 0.12 & 0.12 & 0.12 & 0.11 & 0.17 & 0.16 & 0.11 & 0.12 & 2.37 & 1.29 & 0.63 & 0.94 \\
\hline$S$ & 16.44 & 5.34 & 17.86 & 5.00 & 18.32 & 6.07 & 15.79 & 4.08 & 14.49 & 11.62 & 85.01 & 49.74 \\
\hline $\mathrm{K}$ & 4.28 & 1.44 & 4.82 & 1.99 & 5.21 & 2.34 & 4.42 & 1.43 & 11.02 & 7.80 & 16.82 & 8.51 \\
\hline $\mathrm{Na}$ & 10.81 & 1.89 & 11.24 & 1.33 & 12.90 & 3.62 & 15.02 & 3.82 & 44.83 & 11.70 & 29.39 & 9.74 \\
\hline $\mathrm{Mg}$ & 6.23 & 0.99 & 6.46 & 0.99 & 6.80 & 1.31 & 6.32 & 1.02 & 12.42 & 1.51 & 18.97 & 5.98 \\
\hline $\mathrm{Ca}$ & 39.17 & 10.38 & 40.94 & 10.99 & 42.05 & 11.11 & 43.01 & 11.21 & 57.89 & 18.50 & 104.54 & 37.67 \\
\hline $\mathrm{Al}$ & 0.94 & 0.76 & 0.95 & 0.78 & 1.17 & 1.40 & 0.96 & 1.29 & 0.12 & 0.11 & 0.30 & 0.45 \\
\hline As & 0.002 & 0.002 & 0.003 & 0.002 & 0.003 & 0.003 & 0.004 & 0.003 & 0.005 & 0.005 & 0.004 & 0.004 \\
\hline $\mathrm{Ba}$ & 0.103 & 0.019 & 0.101 & 0.015 & 0.100 & 0.014 & 0.103 & 0.011 & 0.088 & 0.025 & 0.085 & 0.030 \\
\hline $\mathrm{Cd}$ & 0.000 & 0.000 & 0.000 & 0.000 & 0.000 & 0.000 & 0.000 & 0.000 & 0.000 & 0.000 & 0.000 & 0.000 \\
\hline Co & 0.000 & 0.000 & 0.001 & 0.000 & 0.000 & 0.000 & 0.000 & 0.000 & 0.000 & 0.000 & 0.001 & 0.001 \\
\hline $\mathrm{Cr}$ & 0.001 & 0.001 & 0.001 & 0.001 & 0.001 & 0.001 & 0.001 & 0.001 & 0.000 & 0.000 & 0.001 & 0.001 \\
\hline $\mathrm{Cu}$ & 0.002 & 0.001 & 0.002 & 0.001 & 0.002 & 0.002 & 0.002 & 0.001 & 0.002 & 0.003 & 0.001 & 0.002 \\
\hline $\mathrm{Fe}$ & 0.680 & 0.371 & 0.707 & 0.400 & 0.776 & 0.701 & 0.636 & 0.666 & 0.291 & 0.173 & 0.412 & 0.382 \\
\hline $\mathrm{Mn}$ & 0.292 & 0.281 & 0.267 & 0.198 & 0.196 & 0.106 & 0.157 & 0.089 & 0.128 & 0.131 & 1.122 & 1.278 \\
\hline $\mathrm{Ni}$ & 0.006 & 0.002 & 0.006 & 0.002 & 0.006 & 0.002 & 0.005 & 0.002 & 0.003 & 0.002 & 0.006 & 0.003 \\
\hline $\mathrm{Pb}$ & 0.002 & 0.002 & 0.001 & 0.002 & 0.003 & 0.006 & 0.003 & 0.004 & 0.000 & 0.001 & 0.001 & 0.001 \\
\hline $\mathrm{Sr}$ & 0.135 & 0.027 & 0.137 & 0.024 & 0.141 & 0.027 & 0.135 & 0.024 & 0.213 & 0.027 & 0.299 & 0.062 \\
\hline V & 0.001 & 0.001 & 0.001 & 0.001 & 0.001 & 0.002 & 0.001 & 0.002 & 0.001 & 0.001 & 0.001 & 0.002 \\
\hline $\mathrm{Hg}$ & 0.00 & 0.00 & 0.00 & 0.00 & 0.00 & 0.00 & 0.00 & 0.00 & 0.00 & 0.00 & 0.00 & 0.00 \\
\hline $\mathrm{Zn}$ & 0.008 & 0.005 & 0.006 & 0.003 & 0.006 & 0.004 & 0.005 & 0.004 & 0.006 & 0.004 & 0.004 & 0.004 \\
\hline
\end{tabular}

Table 2b: Summary data of elements concentrations (in mg/l except EC: $\mu$ S/cm and pH: no unit) in Gans creek (G1, G2, G3, G4), domestic sewage lagoon overflow (T1) and confined animal lot lagoon overflow (H1) samples for the sampling period May 2009-April 2010.

relative to DSLO (Table 2a) samples. On an annual scale, the DSLO was the highest contributor of $\mathrm{B}, \mathrm{NH}_{3}-\mathrm{N}, \mathrm{Cl}$, TN, TP and TOC compared to CALLO corresponding annual values.

\section{Gans Creek chemistry}

Nutrient criteria are presently not available for Missouri streams but the EPA drinking water standards, Missouri department of natural resources criteria for protection of aquatic life [30] and Australia water quality guidelines [31] were used to assess the quality of Gans Creek. Gans Creek was characterized as an intermittent and perennial stream. Water quality constituents were found to vary with the flow regime during the seasons. Ambient and water temperatures observed followed typical Missouri seasonal pattern of four seasons (spring, summer, fall and winter). Water temperature was $\leq 4^{\circ} \mathrm{C}$ in the winter months and as high as $29^{\circ} \mathrm{C}$ during the summer period. The $\mathrm{pH}$ of Gans Creek (range: 7.00-8.3) can be classified as slightly above neutral throughout the sampling months and this implied no major harm to biota when compared to EPA drinking water guideline. Electrical conductivity (EC) (in $\mu \mathrm{S} \mathrm{cm}^{-1}$ ) varied considerably from 139.3 (G1: most upstream site) in August 2009 to 690 (G4: most downstream site) in February 2010.31\% of samples exceeded the upper EC value $\left(250\right.$ in $\left.\mu \mathrm{S} \mathrm{cm}^{-1}\right)$ for slightly disturbed water bodies (Table 2c). Piper plot of the hydrochemical facie for Gans Creek samples is shown in Figure 3a. Gans Creek samples can be classified as a $\mathrm{Ca}^{2++}-\mathrm{Mg}^{2+}-\mathrm{Cl}^{-}-\mathrm{SO}_{4}^{3-}$ type water type but dominated mostly by $\mathrm{Ca}^{2}+$ and $\mathrm{SO}_{4}^{3-}$ ions.

The seasonal dataset had highest spatial difference for EC, Na, $\mathrm{Mg}, \mathrm{K}, \mathrm{Ca}, \mathrm{Cl}^{-}$and $\mathrm{SO}_{4}^{3}$ during the winter period. On an annual scale, $\mathrm{Ca}$ was the most prominent element and the order of abundance of major cations and anions followed the trend we observed for the sewage overflows. $\mathrm{NO}_{3}-\mathrm{N}$ ranged from nondetectable- $8.9 \mathrm{mg} \mathrm{L}^{-1}$ in the samples, and it was the most dominant $\mathrm{N}$ form of combined nitrogen. 
Citation: Ikem A, Broz B, Garth J, Tesfaye S, Lin C (2013) Evaluation of Surface Water Quality Impacted by Sewage Overflows from Animal and Residential Lagoon Systems using Principal Component Analysis. J Environ Anal Toxicol 3: 197. doi: 10.4172/2161-0525.1000197

Page 5 of 8

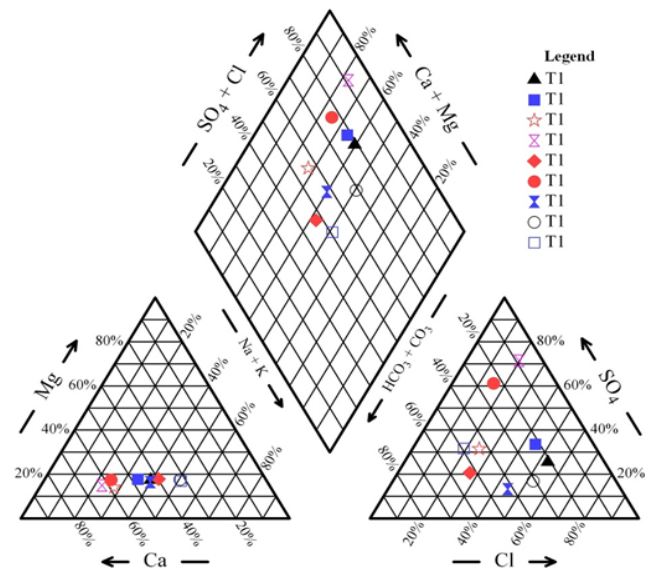

Figure 2a: Piper diagram showing domestic sewage lagoon overflow (T1) hydrochemical regime.

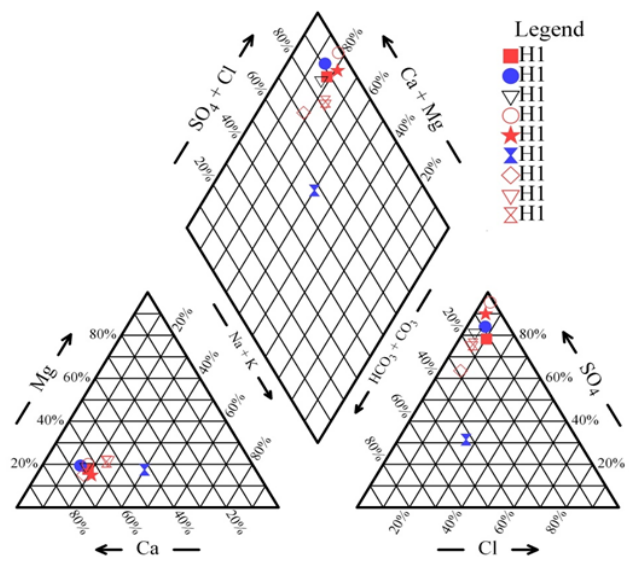

Figure 2b: Piper diagram showing confined animal lot lagoon overflow $(\mathrm{HI})$ hydrochemical regime.

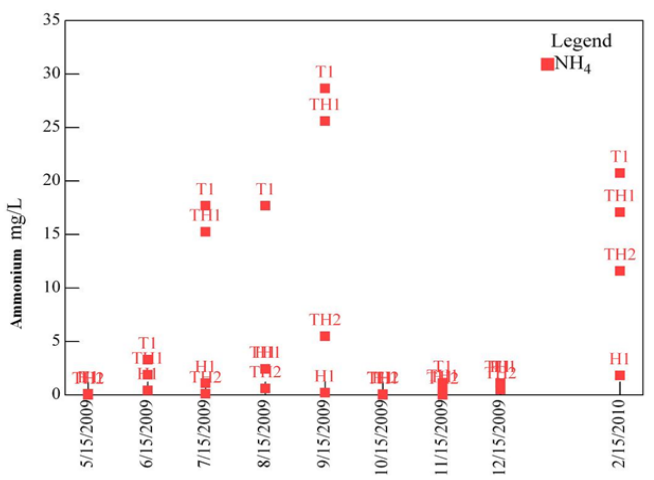

Figure 2c: Time series plot of ammonium concentrations in domestic sewage lagoon overflow (DSLO) and confined animal lot lagoon overflow (CALLO) samples (May 2009-February 2010).
It accounted for between 94-97\% and 30-94\% in May 2009 (spring) and February 2010 (winter) respectively. Annual average for $\mathrm{NO}_{3}-\mathrm{N}$ observed for Gans Creek was below the $10 \mathrm{mg} \mathrm{L}^{-1}$ drinking water guideline. Nitrate usually is the dominant form of combined nitrogen in natural waters; however, the presence of nitrates at levels greater than $5 \mathrm{mg} \mathrm{L}^{-1}$ may reflect unsanitary conditions since one major source of nitrates in aquatic systems is human and animal excreta [32].

Figure $3 \mathrm{~b}$ shows the time series plot of $\mathrm{NH}_{4}^{+}$concentrations in Gans Creek during the sampling period. The monthly recorded data for $\mathrm{NH}_{3}-\mathrm{N}$ ranged from nondetectable- $0.69 \mathrm{mg} \mathrm{L}^{-1}$. The concentrations of $\mathrm{NH}_{3}-\mathrm{N}$ at $\mathrm{G} 3$ site were highest in September 2009 and February 2010 and was probably derived from both CALLO and DSLO. Other forms of nitrogen in Gans Creek were related to diffuse pollution from upstream areas. Ammonia, nitrite and nitrate constitute the various forms of inorganic nitrogen. Apart from dissolved oxygen (DO), unionized $\mathrm{NH}_{3}$ [33] and $\mathrm{NH}_{4}^{+}$[34] are important surface water parameters that can drastically impact the biological community structure at high concentrations. Stream alkaline condition and temperature affect the level of un-ionized $\mathrm{NH}_{3}$. The EPA 1999 criteria at $\mathrm{pH} 8$ and $25^{\circ} \mathrm{C}$ for acute and chronic $\mathrm{NH}_{3}$ levels are $5.6 \mathrm{mg} \mathrm{N} \mathrm{L}^{-1}$ salmon present and 1.2 $\mathrm{mg} \mathrm{N} \mathrm{L}^{-1}$ fish early life stages present respectively $[35,36]$. Approximately $83 \%$ of Gans Creek samples exceeded the ANZECC default trigger value of $0.01 \mathrm{mg} / \mathrm{L}$ ammonia (Table 2c) designated for physical and chemical stressors in tropical Australia for slightly disturbed ecosystems for Lowland river [31].

TP concentrations were high in spring and fall compared to winter (TP in Gans Creek ranged from 0.07-0.31 $\mathrm{mg} \mathrm{L}^{-1}$ ). The mean seasonal concentration of all sampled sites on Gans Creek exceeded the TP trigger value (10 $\mu \mathrm{g} \mathrm{L}^{-1}$; Table $\left.2 \mathrm{c}\right)$ for slightly disturbed lowland rivers [31]. Phosphorus is non-toxic, but high concentrations can result in excess growth of aquatic plants with various consequences to fish species. The dynamics of nitrogen and phosphorus in a stream may control the numbers and types of the biological community structure and eutrotrophication process. Phosphorus recorded for Gans Creek was mostly derived from household detergent present in DSLO samples.

The annual seasonal mean (range: 1.11-1.30 $\mathrm{mg} \mathrm{L}^{-1}$ ) of $\mathrm{Al}$ in Creek samples was generally higher than the trigger value $\left(0.055 \mathrm{mg} \mathrm{L}^{-1}\right.$ $\mathrm{Al})$ recommended for disturbed lowland river [31] and the Missouri Department of Natural Resources acute Al level $\left(0.75 \mathrm{mg} \mathrm{L}^{-1)}\right.$ for protection of aquatic life. However, $\mathrm{Zn}$ levels were generally below 18 $\mu \mathrm{g} \mathrm{L}^{-1}$. The concentrations of B were highest during spring (G2: 0.045 $\left.\mathrm{mg} \mathrm{L}^{-1}\right)$ and summer (G3: $\left.0.060 \mathrm{mg} \mathrm{L}^{-1}\right)$ periods. The DSLO wastewater was the major source of B in Gans Creek during the four seasons.

\section{Results for PCA}

PCA reduced the data matrix, extracted the most influencing parameters and explained the total variability in the dataset consisting of 31 analytical parameters or principal components (PCs). Each PC is represented by 31 variables with their correlation loadings constrained between +1 and -1 . The best interpretation of a given PC is to associate the loadings of each variable with the possible sources of contamination at the study area. Table 3 shows our observed initial eigenvalues, cumulative variance, rotation sums of squared loadings, communalities and the correlation loadings on the PCs for the variables. Previous report classified factor loadings as 'strong', 'moderate', and 'weak' corresponding to absolute loading values of $>0.75,0.75-0.50$ and 0.50 0.30 , respectively [35]. In this study, four varimax rotated principal components (RC1, RC2, RC3, and RC4) represented approximately $60 \%$ of the total variability of the entire dataset. These rotated components 
Citation: Ikem A, Broz B, Garth J, Tesfaye S, Lin C (2013) Evaluation of Surface Water Quality Impacted by Sewage Overflows from Animal and Residential Lagoon Systems using Principal Component Analysis. J Environ Anal Toxicol 3: 197. doi: 10.4172/2161-0525.1000197

Page 6 of 8

\begin{tabular}{|c|c|c|c|c|c|c|c|c|c|c|c|c|c|c|c|}
\hline Site & $\mathrm{pH}$ & EC & $\mathrm{Al}$ & $\mathrm{Fe}$ & B & $\mathrm{Pb}$ & $\mathrm{Zn}$ & $\mathrm{Mn}$ & $\mathrm{NH}_{3}-\mathrm{N}$ & $\mathrm{NO}_{3}-\mathrm{N}$ & $\mathrm{Cl}-$ & $\mathrm{SO}_{4}{ }^{2-}$ & $\mathrm{TN}$ & TP & TOC \\
\hline *Trigger & $7-8$ & $20-250$ & & & & & & & 0.01 & & & & $0.2-0.3^{a}$ & 0.01 & \\
\hline${ }^{* *}$ Trigger & & & $0.055^{b}$ & - & 0.37 & 0.0034 & 0.008 & 1.9 & $0.9^{c}$ & $0.7^{\mathrm{d}}$ & & & & & \\
\hline
\end{tabular}

EC: electrical conductivity; TP: total phosphorus; $\mathrm{NH}_{3}-\mathrm{N}$ : ammonia-nitrogen; $\mathrm{NO}_{3}-\mathrm{N}$ : nitrate-nitrogen; TOC: total organic carbon; $\mathrm{SO}_{4}{ }^{2}-$ : sulfate.

${ }^{*}$ ANZECC default trigger values designated for physical and chemical stressors in tropical Australia for slightly disturbed ecosystems for Lowland river [31]. Trigger values are used to assess risk of adverse effects due to nutrients, biodegradable organic matter and $\mathrm{pH}$ in various ecosystem types.

${ }^{* *}$ ANZECC Trigger values for toxicants at $95 \%$ level of protection of species for typical slightly-moderately disturbed systems [31].

aLower values from rivers draining rainforest catchments.

${ }^{b}$ Trigger value of aluminum at $\mathrm{pH}>6.5$.

cTotal ammonia as $\mathrm{NH}_{3}-\mathrm{N}$ at $\mathrm{pH} 8$.

${ }^{\mathrm{d}}$ The values have been calculated using a hardness of $30 \mathrm{mg} \mathrm{l}^{-1} \mathrm{CaCO}_{3}$.

Table 2c: Freshwater quality trigger values and guidelines.

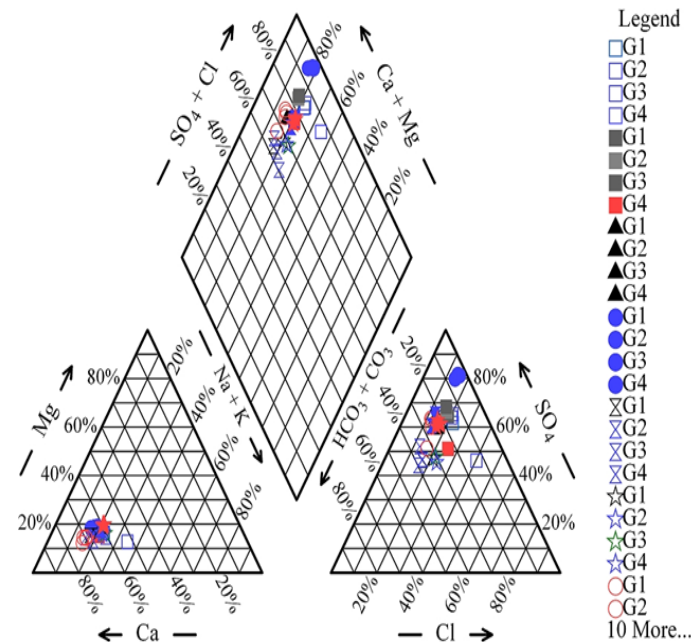

Figure 3a: Piper diagram showing hydrochemical regime of Gans Creek samples.

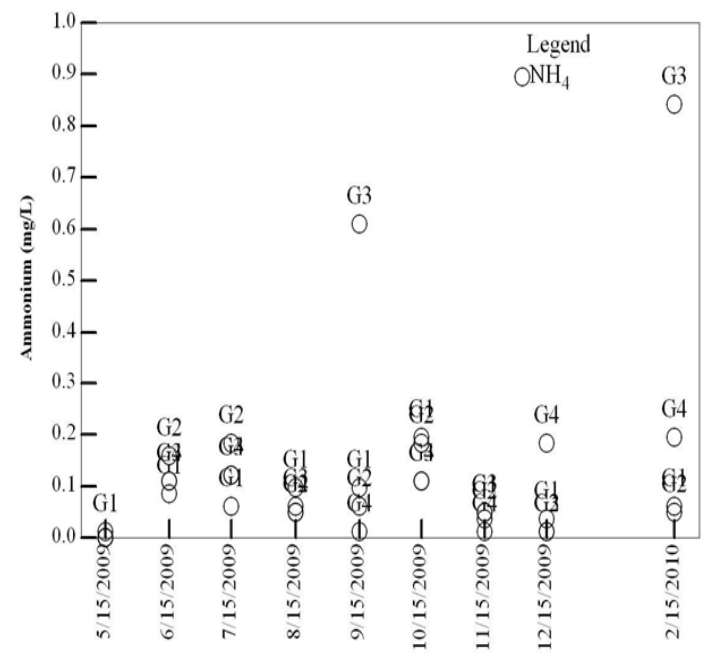

Figure 3b: Time series plot of ammonium concentrations in Gans Creek samples (May 2009-February 2010).

best explained the analytical variables and controlling processes at the sites.

The most significant analytical variables on each of the four components were as follows: RC1 had the highest variance (20\%) in the dataset and the most significant controlling variables on this component were $\mathrm{Mg}, \mathrm{Ca}, \mathrm{SO}^{3-}, \mathrm{Sr}, \mathrm{EC}, \mathrm{pH}$, and $\mathrm{Na}$. Strong positive correlations (>0.79) were obtained for $\mathrm{EC}, \mathrm{Mg}, \mathrm{Ca}, \mathrm{Sr}$ and $\mathrm{SO}_{4}^{3-}$ and moderate positive correlations were for $\mathrm{pH}(0.56)$ and $\mathrm{Na}(0.63)$. The direct positive relationships of these variables on $\mathrm{RC} 1$ were as a result of the high solubilities of the elements in solution with a proportionate increase in EC value. From the correlation loadings on $\mathrm{RC} 1$, the solubilities of $\mathrm{Mg}, \mathrm{Ca}, \mathrm{Sr}, \mathrm{Na}$ and $\mathrm{SO}_{4}^{3-}$ were influenced by $\mathrm{pH}$ at G1, G2, G3 and G4 sites. Therefore, mineralization of cations and anions (natural controlling process) in Gans Creek was the dominant factor that accounted for the $20 \%$ variability of the dataset in the study area.

RC2 accounted for approximately $19 \%$ of the total variance of our dataset, and the most significant controlling experimental variables on $\mathrm{RC} 2$ were $\mathrm{PO}_{4}^{3-}, \mathrm{TN}, \mathrm{B}, \mathrm{NH}^{+}, \mathrm{Na}, \mathrm{Cl}-$, and $\mathrm{NO}^{3-}$. The parameters $\mathrm{PO}_{4}^{3-}, \mathrm{B}, \mathrm{NH}_{4}^{+}$and $\mathrm{TN}$ were the most positively correlated variables $(>0.80)$ followed by $\mathrm{Na}, \mathrm{Cl}$ - and $\mathrm{NO}_{3}{ }^{-}$with moderate correlations $(0.55-$ 0.72). The DSLO was the major contributor of $\mathrm{B}$ (Table 2a), and $\mathrm{NH}_{4}^{+}$ and TP (Figure 3a) to Gans Creek relative to CALLO. Therefore, the associations of these variables on RC2 represent the contributions of DSLO and CALLO and can be called the "sewage overflow factor". Thus, the sewage overflow factor represented approximately $31 \%$ influence on the quality of Gans Creek Creek from the four major rotated components.

The variables $\mathrm{Fe}, \mathrm{Al}, \mathrm{Cr}, \mathrm{V}$ and $\mathrm{NO} 3$ - had strong positive associations on RC3. Inorganic carbon was also strong but negatively correlated. The strongly correlated variables identified on RC3 represented the influence of diffuse pollution such as runoffs and other human activities upstream of Gans Creek. RC3 accounted for approximately $12 \%$ of the total variance in the dataset and represented 20\% influence on Gans Creek water quality. RC4 accounted for $9 \%$ of the total variability of the dataset, and the strongly correlated variables on this component were $\mathrm{Cu}, \mathrm{Cd}, \mathrm{V}, \mathrm{Zn}$ and TOC. These variables on $\mathrm{RC} 4$ probably were probably related to runoffs from cattle grazing areas near the stream segment.

\section{Additional monitoring of ammonia-nitrogen}

Figure $4 \mathrm{a}$ and $\mathrm{b}$ presents the result of additional monitoring of ammonia-nitrogen at the lagoon overflows (DSLO and CALLO) and at Gans Creek sampling sites respectively from March 2010-July 2011. The DSLO showed the highest export of ammonia-nitrogen during the sampling months as equally observed in the 2009-2010 sampling regime. Irrespective of the dilution factor due to volume of water downstream of Gans Creek, ammonia impact was noticeable downstream (G3) during February 2011. This additional data on ammonia suggested a consistent export of ammonia-nitrogen into Gans Creek.

\section{Conclusions}

This study evaluated the water quality of Gans Creek, the characteristics of human and animal sewage wastewater overflows, and 
Citation: Ikem A, Broz B, Garth J, Tesfaye S, Lin C (2013) Evaluation of Surface Water Quality Impacted by Sewage Overflows from Animal and Residential Lagoon Systems using Principal Component Analysis. J Environ Anal Toxicol 3: 197. doi: 10.4172/2161-0525.1000197

Page 7 of 8

\begin{tabular}{|c|c|c|c|c|c|}
\hline \multirow[t]{2}{*}{ Variable } & \multicolumn{4}{|c|}{ Rotated Components (RC) } & \multirow[t]{2}{*}{ Communalities } \\
\hline & RC1 & RC2 & RC3 & RC4 & \\
\hline Magnesium & 0.905 & & & & 0.958 \\
\hline Calcium & 0.902 & & & & 0.858 \\
\hline Sulfate & 0.898 & & & & 0.915 \\
\hline Strontium & 0.889 & & & & 0.920 \\
\hline $\begin{array}{l}\text { Electrical } \\
\text { conductivity }\end{array}$ & 0.793 & & & & 0.936 \\
\hline $\mathrm{pH}$ & 0.625 & & & & 0.450 \\
\hline Phosphate & & 0.904 & & & 0.866 \\
\hline Total nitrogen & & 0.875 & & & 0.788 \\
\hline Boron & & 0.871 & & & 0.775 \\
\hline Ammonium & & 0.831 & & & 0.736 \\
\hline Sodium & 0.555 & 0.722 & & & 0.852 \\
\hline Chloride & & 0.661 & & & 0.688 \\
\hline Nitrite & & 0.546 & & & 0.321 \\
\hline Iron & & & 0.827 & & 0.870 \\
\hline Aluminum & & & 0.782 & & 0.847 \\
\hline Chromium & & & 0.768 & & 0.749 \\
\hline Inorganic carbon & & & -0.551 & & 0.782 \\
\hline Nitrate & & & 0.532 & & 0.646 \\
\hline Copper & & & & 0.746 & 0.691 \\
\hline Cadmium & & & & 0.678 & 0.491 \\
\hline Vanadium & & & 0.634 & 0.641 & 0.821 \\
\hline Zinc & & & & 0.587 & 0.664 \\
\hline Total organic carbon & & & & -0.507 & 0.782 \\
\hline Barium & & & & & 0.599 \\
\hline Potassium & & & & & 0.606 \\
\hline Nickel & & & & & 0.476 \\
\hline Lead & & & & & 0.062 \\
\hline Manganese & & & & & 0.805 \\
\hline Cobalt & & & & & 0.743 \\
\hline Arsenic & & & & & 0.492 \\
\hline Mercury & & & & & 0.39 \\
\hline Initial Eigenvalues & 9.313 & 4.299 & 3.264 & 2.16 & \\
\hline Cumulative\% & 30.042 & 43.91 & 54.439 & 61.406 & \\
\hline $\begin{array}{l}\text { Rotation Sums of } \\
\text { Squared Loadings }\end{array}$ & 6.096 & 5.934 & 3.687 & 2.931 & \\
\hline Cumulative\% & 19.665 & 38.808 & 50.7 & 60.153 & \\
\hline
\end{tabular}

Extraction Method: Principal Component Analysis

Rotation Method: Varimax with Kaiser Normalization

Table 3: Rotated loadings of 31 experimental variables on significant principal components for Gans Creek, DSLO and CALLO dataset.

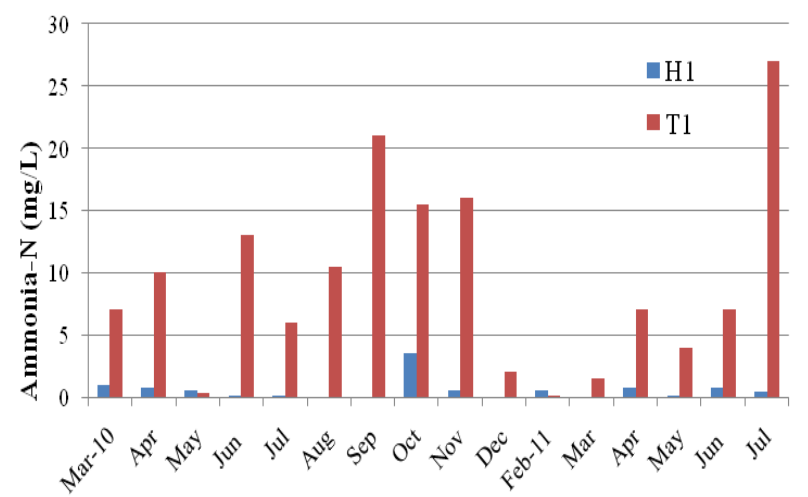

Figure 4a: Bar chart of ammonia- $\mathrm{N}$ concentrations in domestic sewage lagoon overflow (DSLO) and confined animal lot lagoon overflow (CALLO) samples (March 2010-July 2011).

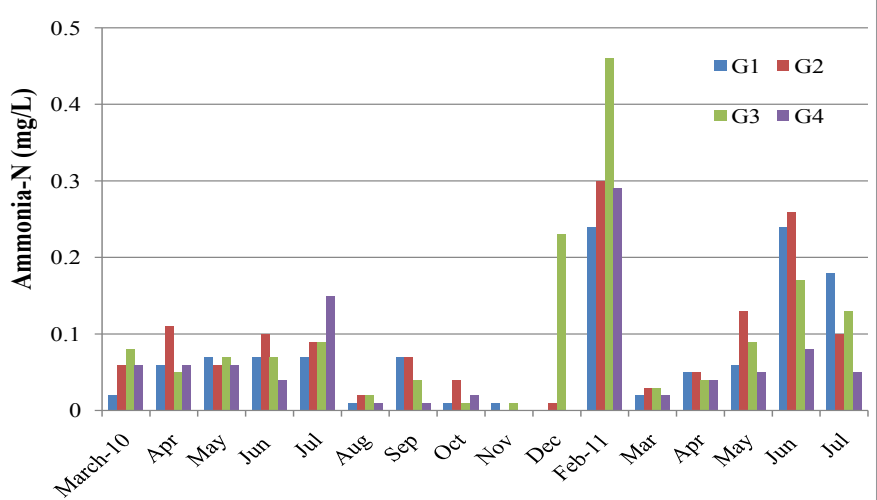

Figure 4b: Bar chart of ammonia- $\mathrm{N}$ concentrations in Gans Creek samples (March 2010-July 2011).

their impact to Gans Creek. Throughout the sampling period, Gans Creek water chemistry was dominated by major cationic and anionic species. We observed the highest spatial difference in $\mathrm{EC}, \mathrm{Na}, \mathrm{Mg}$, $\mathrm{K}, \mathrm{Ca}, \mathrm{Cl}^{-}$and $\mathrm{SO}_{4}^{3-}$ values during the winter period. Comparison of CALLO and DSLO datasets showed that the DSLO was the highest contributor of $\mathrm{NH}_{3}-\mathrm{N}, \mathrm{Cl}-$, TP, TOC and B to Gans Creek. PCA result explained approximately $60 \%$ of the total variability of the analytical dataset in this study. Mineralization due to natural processes, sewage overflow factor, diffuse pollution upstream of Gans Creek and runoff effects from cattle grazing areas near the study sites were the most controlling processes at the sampling area. Over twenty analytical variables were found to be important in the chemistry of Gans Creek and heavy impact on Gans Creek quality was due to the presence of dissolved materials and ammonia.

A nutrient reduction plan was implemented by the Beef research facility manager in 2010 to mitigate the pollution problems at the study site. Some of the nutrient reduction strategies implemented were: creation of protected riparian area along sections of the Creek, nutrient management plan in place for application of manure, grass filter strips along the Creek corridor, set back distances from Creek and fencing out livestock from Creek main channel. We recommend that the wastewater from the DSLO should be continually evaluated for effectiveness and pollution reduction plan be implemented to reduce ammonia-nitrogen in sewage outflows. If possible, channeling of wastewater to an artificial constructed lagoon that allows for effective treatment and discharge may be considered.

\section{Acknowledgement}

This research was funded by the United States Department of Agriculture (Evans-Allen Grant \#2011-006). Authors are grateful to Professor Monty Kerley for granting access to the University of Missouri beef research farm. Also we are thankful to the anonymous reviewers and editorial board for their review suggestions.

\section{References}

1. Zimbelman RG, Wilson LL, Bennett MB, Curtis SE (1995) Public image of animal agriculture in the United States. Livestock Production Science 43: 153-159.

2. EPA (United States Environmental Protection Agency) (2009) National Water Quality Inventory: Report to Congress. 2004 Reporting Cycle.

3. Missouri Department of Natural Resources (2012) Missouri water quality report (Section 305(b) Report). Water Protection Program, Jefferson City, Missouri 81.

4. Cutrofello M, Durant JL (2007) Fate of high loads of ammonia in a pond and wetland downstream from a hazardous waste disposal site. Chemosphere 68: 1365-1376. 
Citation: Ikem A, Broz B, Garth J, Tesfaye S, Lin C (2013) Evaluation of Surface Water Quality Impacted by Sewage Overflows from Animal and Residential Lagoon Systems using Principal Component Analysis. J Environ Anal Toxicol 3: 197. doi: 10.4172/2161-0525.1000197

5. Spongberg AL, Witter JD (2008) Pharmaceutical compounds in the wastewater process stream in Northwest Ohio. Science of The Total Environ 397: 148-157.

6. Brown KD, Kulis J, Thomson B, Chapman TH, Mawhinney DB (2006) Occurrence of antibiotics in hospital, residential, and dairy effluent, municipa wastewater, and the Rio Grande in New Mexico. Science of The Total Environ 366: 772-783.

7. Madoux-Humery A, Dorner S, Sauvé S, Aboulfadl K, Galarneau M, et al. (2013) Temporal variability of combined sewer overflow contaminants: Evaluation of wastewater micropollutants as tracers of fecal contamination. Water Research 47: 4370-4382

8. Phillips PJ, Chalmers AT, Gray JL, Kolpin DW, Foreman WT, et al. (2012) Combined sewer overflows: an environmental source of hormones and wastewater micropollutants. Environ Sci Tech 46: 5336-5343.

9. Ahrens L, Felizeter S, Sturm R, Xie Z, Ebinghaus R (2009) Polyfluorinated compounds in wastewater treatment plant effluents and surface waters along the River Elbe, Germany. Mar Poll Bull 58: 1326-1333.

10. Wu BZ, Feng TZ, Sree U, Chiu KH, Lo JG (2006) Sampling and analysis of volatile organics emitted from wastewater treatment plant and drain system of an industrial science Park. Analytica Chimica Acta 576: 100-111.

11. Marcussen H, Dalsgaard A, Holm PE (2008) Content, distribution and fate of 33 elements in sediments of rivers receiving wastewater in Hanoi, Vietnam. Environmental Pollution 155: 41-51.

12. Withers PJA, Jarvie HP, Stoate C (2011) Quantifying the impact of septic tank systems on eutrophication risk in rural headwaters. Environment International 37: 644-653.

13. Lowery TA (1998) Modelling estuarine eutrophication in the context of hypoxia, nitrogen loadings, stratification and nutrient ratios. Journal of Environmental Management 52: 289-305.

14. EPA (United States Environmental Protection Agency) (2005) Decentralized Wastewater Treatment Systems: Program Strategy. Office of Water, Cincinnati.

15. Gill LW, O'Luanaigh N, Johnston PM, Misstear BDR, O'Suilleabhain C (2009) Nutrient loading on subsoils from on-site wastewater effluent, comparing septic tank and secondary treatment systems. Water Research 43: 2739-2749.

16. Missouri Department of Natural Resources (2013) Total Maximum Daily Load Information Sheet Gans Creek. Water Protection Program, Jefferson City.

17. APHA (American Public Health Association) (1998) Standard Methods for the Examination of Waters and Wastewaters, 20th edn, Washington, DC.

18. Vega M, Pardo R, Barrado E, Debán L (1998) Assessment of seasonal and polluting effects on the quality of river water by exploratory data analysis. Water Research 32: 3581-3592.

19. Alberto WD, del Pilar DM, Valeria AM, Fabiana PS, Cecilia HA, et al. (2001) Pattern Recognition Techniques for the Evaluation of Spatial and Temporal Variations in Water Quality. A Case Study: Suquia River Basin (CórdobaArgentina). Water Research 35: 2881-2894.
20. Singh KP, Malik A, Mohan D, Sinha S (2004) Multivariate statistical techniques for the evaluation of spatial and temporal variations in water quality of Gomt River (India)-a case study. Water Research 38: 3980-3992.

21. Gazzaz NM, Yusoff MK, Ramli MF, Aris AZ, Juahir H (2012) Characterization of spatial patterns in river water quality using chemometric pattern recognition techniques. Mar Pollut Bull 64: 688-698.

22. Esbensen K, Guyot D, Westad F, Houmoller LP (2004) Multivariate Analysis in Practice, 5th edn, CAMO Technologies, Woodbridge, NJ, USA.

23. Ouyang Y (2005) Evaluation of river water quality monitoring stations by principal component analysis. Water Research 39: 2621-2635.

24. Olsen RL, Chappell RW, Loftis JC (2012) Water quality sample collection, data treatment and results presentation for principal components analysis-literature review and Illinois River watershed case study. Water Research 46: 3110-3122.

25. Manly BFJ (1986) Multivariate Statistical Methods: A Primer, 2nd edn, Chapman \& Hall, London-New York. Biometric Journal 30: 874-875

26. Kaiser HF (1958) The varimax criterion for analytic rotation in factor analysis Psychometrika 23: 187-200.

27. SPSS (2006) SPSS version 15 for Windows, SPSS Inc., Chicago, IL, USA.

28. EPA (United States Environmental Protection Agency) (2009) 2009 Edition of the Drinking Water Standards and Health Advisories.

29. Fox KK, Cassani G, Facchi A, Schröder FR, Poelloth C, et al. (2002) Measured variation in boron loads reaching European sewage treatment works. Chemosphere 47: 499-505.

30. Missouri Department of Natural Resources (2011) Rules of Department of Natura Resources, Division 20-Clean Water Commission, Chapter 7-Water quality.

31. ANZECC water quality guidelines (2000) Aquatic ecosystems, Australian and New Zealand Environment and Conservation Council and Agriculture and Resource Management Council of Australia and New Zealand.

32. McNeely RN, Neimanis VP, Dwyer L (1979) Water quality source book: A guide to water quality parameters. Ottawa, Canada 89.

33. Emerson K, Russo RC, Lund RE, Thurston RV (1975) Aqueous ammonia equilibrium calculations: Effects of $\mathrm{pH}$ and temperature. J Fish Res Board Can 32: $2379-2383$.

34. EPA(United States Environmental Protection Agency) (1999) Update of ambient water quality criteria for ammonia. EPA 882-R-99-014. US Environmental Protection Agency Office of Water, Washington, DC, USA.

35. Liu, CW, Lin KH, Kuo YM (2003) Application of factor analysis in the assessment of groundwater quality in a blackfoot disease area in Taiwan. Sci Total Environ 313: 77-89.

36. EPA (United States Environmental Protection Agency) (2011) Health and Ecological Criteria Division (4304T), Washington, DC. 